Jafarova L.A., Mammadov V.G.•

DOI: 10.25108/2304-1730-1749.iolr.2017.51.130-166

\title{
Implementation of the UNESCO Bioethics Core Curriculum: International experience and Azerbaijan
}

\begin{abstract}
It is analyzed the importance of UNESCO's bioethics program, various methods and aspects of its use and its role in education. The experience of application of the program in various countries of the world is researched. The experience of Azerbaijan in the sphere of development of bioethics as a scientific discipline and successes of the country in this area is stated.
\end{abstract}

Keywords: UNESCO program on bioethics; Bioethics Core Curriculum; bioethics education.

Current state of science, especially in the field of biology and medicine, is characterized by the increasing role of ethical aspects with respect to the protection of human rights and dignity. A relatively young field of science - Bioethics has acquired particular importance from this point of view. The importance of ethical principles is becoming increasingly important at the international level, in particular, thanks to the bioethical program that was launched within the framework of the United Nations, namely its structure such as UNESCO. The UNESCO Bioethics Program was established in 1993, and since 2002 it has become one of UNESCO's priority activities [21, p. 77-78]. Thanks to the joint

\footnotetext{
- Jafarova Lala Afig qyzy - candidate for a degree of the Institute for Law and Human Rights of National Academy of Sciences of Azerbaijan (Azerbaijan). E-mail: Lala-J@ hotmail.com

- Mammadov Vugar Gurban oglu - Doctor of Medicine, Professor, a Head of Azerbaijani bureau of UNESCO's International chain of the departments on Bioethics, a Deputy of the Chair of National Committee on Bioethics of the National Academy of Sciences of Azerbaijan (Azerbaijan). E-mail: vumammadov@yahoo.com
} 
efforts of states, individual organizations, including as a result of interaction within the UN, modern international ethical standards are reflected in the adoption of international treaties, declarations, conventions and further introduction of new developed principles into national legislation.

Numerous problems, such as: stem cell research, genetic engineering, cloning, etc. created a lot of questions and concerns. These challenges are not only of social nature, but also include legal, cultural, and, no less important, ethical aspects. Moreover, new global challenges, in particular, resulting from scientific and technological progress have emerged, which cannot remain without attention. That is why, in the present conditions of a rapidly changing world, specialists need new knowledge to navigate in extraordinary ethical and legal situations. However, it is obvious that science can not develop independently, namely, it is very important to train qualified personnel, specialists who will be able to investigate these issues, and through the introduction of appropriate training courses to convey basic bioethical principles and ideas to the general public. To this end, a relevant program was prepared by UNESCO, namely the Bioethics Core Curriculum. With regard to bioethical principles, it should be noted that they are reflected in the Universal Declaration on Bioethics and Human Rights, adopted on October 19, 2005, at the 33rd session of the General Assembly of UNESCO [22, p. 65].

Since the essence of the program is UNESCO's principles, it does not represent a specific bioethical model [22, p. 67]. The curriculum development was the result of activities and efforts, both of UNESCO itself, and by numerous committees, specialists and scientists. Thus, the application of the basic training course within the framework of the Bioethics Program in recent years has become one of the key directions in the educational activities of the Bioethics Committee of UNESCO. It should be noted that the creation of the UNESCO Chair in bioethics was not only an impetus for the development of bioethics as a science, but also allowed to expand the ties of states in educational issues related to 
bioethics. In particular, the Chair is a kind of coordinating body that promotes the establishment of a more successful dialogue between universities and UNESCO, contributing to the expansion of interstate cooperation in this field. The International Bioethics Committee (IBC), which consists of 36 independent experts and the Intergovernmental Bioethics Committee (IGBC), consisting of 36 UNESCO member countries, are consultative bodies operating under the Program. Thus, the implementation of the Program is carried out in four areas: 1) the organization of a discussion forum; 2) rule-making; 3) advisory support and capacity building; 4) education and raising awareness of bioethical issue [21, p.7778].

The first version of the Core Curriculum was prepared in 2008 and to date dozens of universities and institutes have begun to take measures to introduce this program into the educational process. As reported on the official website of UNESCO: "The UNESCO Core Curriculum on bioethics is intended to familiarize university students with the principles of bioethics laid down in the Universal Declaration on Bioethics and Human Rights. Bioethics is not studied at universities in many countries. A core curriculum may prompt them begin their study" [2, p.1]. An important component of the Program is that it is based on international, universally accepted values, including those adopted by UNESCO. That is why the Core Curriculum is a kind of benchmark, the foundation, "it does not impose any particular model or concrete vision of bioethics - it sets out the ethical principles shared by scientists, politicians and health workers in different countries of the world, distinguished by cultural, historical and religious originality" [2, p. 1].

The application of the basic course is reduced not only to the theoretical part, namely, to teaching, but, more importantly, also practical. The course allows students to prepare for the acquisition of new knowledge in the humanities. Nevertheless, the moral side, which is the basis of the program, is designed to fill the vacuum of modern education, which in the future can be used in the field of 
applied sciences. Thus, familiarization with the basic bioethical principles, philosophical problems, etc. creates a basis for identifying new methods of scientific knowledge, which is especially important for future specialists in the field of human rights and medicine [9, p.1]. The study of the basic program is primarily aimed at mastering new skills of information perception, methods of solving bioethical dilemmas and a consistent transition from theoretical knowledge to practical activity.

The very creation of the Program was the result of the natural development of bioethics and the need for educational activities in this field. In the Universal Declaration on Bioethics and Human Rights, much attention is paid to the educational aspect. Therefore, in the section "Promoting the implementation of the Declaration", articles 22 and 23 are of great interest. Article 22 emphasizes the special importance of states not only in the implementation of bioethical principles, but also in the field of education. Article 23 (item 1), the title of which speaks for itself - "Education, training and information in the field of bioethics", notes that "In order to promote the implementation of the principles set forth in this Declaration and to provide a deeper understanding of the ethical impacts of scientific and technological progress, in particular for young people, states should endeavor to promote education and professional training in bioethics, and to promote the implementation of information and knowledge dissemination programs on "bioethics" [27, p. 1]. So, the Declaration can be considered as a kind of legal basis for the application of educational activities in the field of bioethics, and in particular, in the implementation of the basic UNESCO program.

Interest to the Program is observed in many regions. Nevertheless, the basic course at the moment in many states is considered as an integral part of medical ethics, rather than an independent discipline. Only in some countries bioethics is considered a separate discipline. In this respect, it is advisable to get acquainted with the experience of some states, which is of great practical interest. 
In Austria, since 2008, training in bioethics has received a new impetus. Thus, a series of lectures ( 3 semesters, 45 minutes per semester) were presented at the Innsbruck Management Center in the framework of the International Program on Health Management. These lectures were prepared on the basis of the UNESCO Bioethics Core Curriculum. It should be noted that teachers from various fields were involved: philosophy, theology, economics, political science, sociology, biology, etc. The course was opened for students of the Medical University of Innsbruck and the University of Innsbruck and, of course, for the students of the Center for Management. In addition, through the comparative analysis of the existing curriculum and integrating goals from the UNESCO Bioethics Core Curriculum, further development of the curriculum in the field of medicine will be carried out, etc. [7, p. 1] Based on these data, it can be concluded that the application and favorable consequences of the implementation of the program and educational activities in the field of bioethics in Austria have been successfully implemented.

The interest towards the UNESCO program in Bulgaria is evidenced by a number of facts. Implementation of the application of the core curriculum was marked by its translation into Bulgarian in January 2011. The Bioethics Core Curriculum was planned for introduction as a selective course at the Faculty of public health for students of Sofia University of Medicine, for a number of specialties, such as graduate students in the field of "Public Health and Health Management" [4, p.1].

In the Republic of Belarus, the testing of the course was started from February 2010, and it is being conducted at the International Environmental University named after Sakharov, located in the city of Minsk [2, p.1].

Based on data from the official website of the UNESCO Moscow Office [2, p. 1], the 'pilot' testing of the core curriculum has already been conducted at the Moscow State University named after Lomonosov (MSU) in the first semester of 
2009/2010 academic year. Also, in a number of faculties of the Moscow State University, the course was included in the work plan for full-time students. Since, bioethics is included in the State Standard of Training of Biological Specialists of all specializations, the Core Curriculum was used as a guide for acquaintance with bioethical bases.

Significant interest towards the Core Curriculum is observed in Mexico. Among the main specific goals of the Department of Bioethics at the University of Motteray the "cooperation in the piloting, implementation and development of UNESCO's basic bioethics program and e-learning" [26, p. 1] is emphasized.

Among other things, if we talk about the application of the program on a regional scale, we can note a number of universities that have already expressed their interest in the basic course. Thus, among them: in Africa - the University of Science and Technology named after Masinde Muliro (Masinde Muliro University of Science and Technology) in Kenya; In the Arab States - University of Hassan II (Université Hassan II) in Casablanca in Morocco; In the Asia-Pacific region: Kumamoto University in Japan and the University of the Philippines in the Philippines; In the Latin American and Caribbean region: Universidad del Litoral in Argentina, the Sao Paolo State University in Brazil and the Republic University of Uruguay (Universidad de la Republica) [23, p.1].

On a regional scale one of the interesting examples is the Asia-Pacific University Ritsumeikan, which trains students from many countries, primarily from the countries of the Asia-Pacific region, such as Japan, Indonesia, etc. A special course on bioethics for students was developed at this university, which was held in the form of 14 lectures and discussions. Further, on the basis of UNESCO's Bioethics Core Curriculum program, students were provided with material reflecting 15 universal principles of the Universal Declaration on Bioethics and Human Rights. In the course of education, great progress was achieved, including an increase in students' interest in various topics. The results of 
the training were quite impressive, prompting from 2011 to develop bioethics into the reformed program of the international school. [15, p. 362] Thus, the application of the UNESCO program has acquired a global scale and the fact that interest in it is observed in regions having so different historical roots, cultural and moral views, speaks of the truly international and universal nature of bioethics, and Core Curriculum as a means of promoting its dissemination and easier perception on the part of students.

It should be noted that interest in the Core Curriculum is observed not only on the part of individual states, but also within organizations. So, an interesting example is the Commonwealth of Independent States (CIS). As is known, cooperation in the field of science is one of the important directions and tasks of the organization. However, the CIS can hardly be called a classical organization dealing exclusively with science. Nevertheless, in the framework of the Interparliamentary Assembly of the Member States of the Commonwealth of Independent States in 2010 an analytical review was prepared in St. Petersburg on the topic "The state of the teaching of bioethics in the system of medical education in the CIS member states". The publication was the result of a survey and information received, which was prepared through the joint activities of the Forum of Ethics Committees of the CIS Member States, the UNESCO Moscow Office, the Division for the Ethics of Science and Technology of the Social and Human Sciences Sector at UNESCO Headquarters in Paris [10, p. 833].

The very development of this document already speaks about the importance and attention of the organization to the issue of educational activities in the field of bioethics. From this point of view the Core Curriculum is at the moment an integral and key part of the teaching of bioethics. On the official website of UNESCO, the following information is given regarding the said review: "The implementation of world trends, the emergence and development of bioethics is based on the historical experience of interaction between the countries of the 
region and the high level of international cooperation within the Interparliamentary Assembly of CIS and UNESCO member states, which contributed to the development of normative and methodological recommendations and creation of intellectual, personnel and political potential for bringing medical education in the region in accordance with the UNESCO training program on bioethics" [1, p.1].

According to the analytical review, bioethics is introduced into the state education standard in the following countries of the region: the Republic of Moldova, the Russian Federation, the Republic of Tajikistan and the Republic of Uzbekistan. Without dwelling in detail on the very issue of teaching bioethics in the CIS countries, let us note a number of facts concerning on Bioethics Core Curriculum of UNESCO. Thus, on the initiative of the UNESCO Moscow Office, IPA CIS and the Forum of Ethics Committees of the CIS Member States, a legislative concept was developed for cooperation between the countries of the region in bringing medical education in line with UNESCO's Core Curriculum on Bioethics by creating the IPA CIS recommendations, summarizing the stage of this work. In this connection, the IPA of the CIS member states prepared and adopted on May 14, 2009 the relevant recommendations "On the cooperation of the CIS member states to bring medical education in line with UNESCO's Bioethics Core Curriculum" (Annex 2) [25, p. 119], Which are also contained in the analytical review. Thus, the fact of implementation of the basic program becomes obvious not only in a separate state, but also in the whole region, which witnesses the importance of this program.

As for the development of bioethics in Azerbaijan, it is necessary to note the great progress in this field. Being a member of the UN, Azerbaijan has also joined many conventions on the protection of human rights and actively joined the activities of UNESCO, which deals with humanitarian problems. [11, p. 113] As bioethics has become one of the priorities of UNESCO, Azerbaijan as one of the 
active members of the organization pays much attention to this issue. One of the most striking examples of this is the holding, on the initiative of First VicePresident of Azerbaijan, President of the Heydar Aliyev Foundation, UNESCO Goodwill Ambassador Mehriban Aliyeva, of the 18th session of the International Bioethics Committee of UNESCO on May 31-June 2 in Baku. This important event gave a new impetus to the development of bioethics in the country [12, p.1].

Great interest in bioethics is primarily due to the rapid development of medical science in the world and results of scientific and technological progress. The emergence of new ethical dilemmas in this connection raises the need for closer scrutiny of these issues. Active steps are being taken in the application of the UNESCO bioethics program [13, p.1] in Azerbaijan. In this regard, a significant event was the holding on December 24, 2010 in the National Academy of Sciences of Azerbaijan of a scientific symposium on "Implementation of the UNESCO Bioethics Program in Azerbaijan", organized jointly with the National Commission of UNESCO in Azerbaijan and the Main Office of the International Network of Bioethics Chairs of UNESCO [24, p.1].

The Azerbaijan Unit of the UNESCO Chair on Bioethics (hereinafter - the Unit) and the National Committee on Bioethics of UNESCO at the National Academy of Sciences of the Republic of Azerbaijan conduct extensive research in the field of introducing bioethics and medical law in the Republic, their role in legislation, education and teaching. In this field, with the direct participation and initiative of the Unit, numerous articles, monographs have been published, methodical guides and recommendations have been prepared, conferences and seminars have been organized and are being held. Various materials published in the country in this area are devoted to the study of the moral, sociological and security issues faced by modern society, introduction and dissemination of the principles of bioethics in all areas of human activity, studying the experience of foreign countries in dealing with these issues, comparative analysis of existing 
international legal framework and creation of a legal framework in our country [14, p.1].

Moreover, there are great achievements in the application of the Bioethics Core Curriculum. Thus, in 2011 the Curriculum was translated into the Azerbaijani language. This step can be called a key one, since the translation of the program has contributed to its further implementation in the educational process. Also, according to the decision of the Cabinet of Ministers of March 30, 2011, for the first time "Bioethics and medical law" was accepted as a scientific specialization for doctoral and dissertational works. At the same time, national scientists were admitted to research in this direction.

A logical continuation in this direction was the direct application of the program in practice. Since 2011 as a pilot project and since 2014 on a regular base the subject "Bioethics and Medical Law" has been introduced into the educational program of the Law Faculty of the Baku State Institute as an independent discipline. This step can be considered unique because bioethics is generally accepted as part of a course in philosophy or medical ethics. That is why teaching this course to lawyers is quite an innovative step.

It should be noted that one of the most significant events in the field of training of local specialists was the holding of a UNESCO training course on bioethics for teachers on 20-24 August 2012. Such course was held for the first time in the CIS countries. The course was implemented jointly by UNESCO, the Institute on Human Rights of the National Academy of Sciences of Azerbaijan and the National Commission of Azerbaijan for UNESCO. Conducting the training in the country shows interest in the application of the bioethics program, including its successful development [15, p.1]. In general, at this stage, the training of local teachers in the field of bioethics is in the process of formation. Thanks to the efforts and direct participation of the Azerbaijan Unit of the UNESCO Chair in Bioethics, local specialists have the opportunity to exchange and improve their 
knowledge in the field of bioethics, namely participating in annual courses on "Research Methodology and Ethics in Medical Sciences" [8, p.1] as well as, at the Harvard School of Public Health [16, p.1].

The educational process is rather multifaceted. Given the existence of appropriate frameworks aimed at the development of bioethics, if we consider the process of applying the program from the point of view of a step-by-step action in an individual state, it can be presented in the form of the following main stages: 1 ) translation of the program into the national language - this step is a necessary measure that is called upon ensuring the introduction of the course in the educational process; 2) the actual educational part - the conduct of classes in accordance with the basic program. However, it is necessary to note another important stage, which is accompanied by the practical part. Namely, the introduction of the program and the training of students in relevant knowledge can be called a successful outcome of the application of the program. Nevertheless, more important, as it seems to us, is the continued use of the skills and knowledge acquired during the training course. This concerns not only the sphere of students' preparation, but also their further independent work, including the practical application of knowledge in the course of work on the search for new ideas that promote the development of various industries in harmony with bioethical legal principles [17, p.1]. The use of the acquired knowledge in the course of further work in other areas is also one of the main objectives of the course. Bioethical legal principles cover almost all spheres of human activities. Therefore, it seems to us that applying the same skills that students will receive in the course of training in accordance with UNESCO's Core Curriculum can contribute to the development of both bioethics science and the dissemination of ideas about ethical fundamentals of human activities in society in accordance with the Universal Declaration on Bioethics and Human Rights. 
In the issue of teaching, it is important to emphasize the special importance of the role of teachers in the course of education. Students may encounter difficulties in the perception of certain provisions, in this regard, the role of the teacher, who is able to direct the student, acquires a fundamental importance. Of great interest is also the private initiative of individual institutions in the application of bioethics to the educational process during the training of specialists. Thus, a bioethical program was developed at the University of Buffolot, during which "technology of objectively structured clinical examination is applied, using standardized patients to assess bioethics" [6, p.1].

Among other things, it should be noted that the availability of qualified teachers is perhaps one of the most important conditions for the application of the UNESCO program [18, p.1]. But on the other hand, this condition can be simultaneously considered as a consequence of the application of the program. Namely, as a result of the introduction of the program and the training of students, new specialists are trained. It is these very specialists who can be involved in the educational process as teachers in the future. In turn, given that the Core Curriculum is developed on the basis of the Universal Declaration on Bioethics and Human Rights of UNESCO, it can be assumed that acquaintance with the basic ethical principles can be realized not only by students of higher institutions, but also by colleges and even by students within the school curriculum [19, p.1]. And such an approach can provide even wider application of the program.

It is important to note that in the context of the overall protection of human rights, the training of personnel, especially in the field of jurisprudence, is important. Lawyers - in order to protect the rights of citizens in matters of bioethics (patients' rights, informed consent, transplantation, euthanasia, etc.) can rely on the basic legal aspects enshrined in the Declaration and national legislation. Thus, the development of new legal norms and laws in accordance with these principles is another important direction in the implementation of the program. 
The application of the Core Curriculum also has a number of other aspects in public life, connected with the moral and ethical foundations, the responsibility in making certain decisions. In the training of future specialists, especially in the field of medicine, familiarization with the essential legal norms of bioethical principles should become the basis, the foundation for a clear understanding of responsibility to citizens and society as a whole. In addition, during the application of the program and the educational process, additional opportunities are created for establishing dialogue between experts in the field of bioethics, experts in the field of law and medicine, as well as stakeholders from other areas.

An important aspect in the course of application of the program is the need to develop special teaching methods for students. Appropriate structures in the development of the curriculum for bioethics classes need to decide whether to apply multidisciplinary training programs in medical, environmental and scientific ethics, or independent training programs for each particular discipline. Despite the universal nature of the provisions of the basic bioethics program developed by UNESCO, it is necessary to understand that in the process of training students of certain specialties may be interested in some or other provisions to a greater or lesser degree [20, p.1]. Including, the methods of teaching that can be developed individually for certain specialties and even universities.

As already noted, UNESCO's Bioethics Core Curriculum is in constant development. Therefore, in 2011 the continuation of the basic course was issued section 2: teaching materials. The examples and cases presented in the second part enable us to determine our attitude to the dilemmas of life situations and, discussing, finding an acceptable solution on specific examples. That is why the second section offers a wide range of cases that should be considered as assumptions and suggestions, which should be further defined and adapted by teachers. Also in the introductory part it is noted that first of all this section includes the materials of UNESCO and other international organizations. 
However, teachers are encouraged to look for other resources, especially from their countries [3, p.4]. Considering the above, it is possible to draw a conclusion about two important aspects: 1) the role of teachers; and 2) the importance of adapting the program depending on region and moral values accepted in it.

Thus, as international experience and practice in Azerbaijan shows, there is a growing interest in bioethics, including UNESCO's Core Curriculum. In many countries, bioethics has already been introduced into the education system, in others, steps are being taken in this direction. However, an important aspect is that until now, unfortunately, in our country bioethics is studied superficially by students of medical educational institutions. Nevertheless, statistics show that the basic program is the source of knowledge that is universal in nature and involves interest, primarily of lawyers, psychologists, sociologists and other scientists. Since it is the universal nature of the bioethical principles reflected in the basic program that makes it more flexible and opens up ample opportunities for learning.

\section{References}

1. Analiticheskiy obzor bioetiki $\mathrm{v}$ sisteme medicinskogo obrazovaniya $\mathrm{v}$ SNG. Oficialniy site UNESCO (in Russ.) [Analytical review of bioethics in the system of medical education in CIS]. Available at: http://www.unesco.org/ new/ru/ moscow/ about-this-office/single-view/news/analytical_review_on_bioethics_and_ medical_education_in_cis/

2. Buro UNESCO v Moskve. Oficialniy site UNESCO (in Russ.) [UNESCO Unit in Moscow]. Available at: http://www.unesco.org/new/ru/moscow/about-thisoffice/single-view/news/unesco_bioethics_core_curriculum_is_now_available_in _russian/

3. Bioethics Core Curriculum Section 2: study materials Ethics Education Programme, 2011. p. 4 [in Eng]. Available at: http://unesdoc.unesco.org/images/ 0021/002109/210933e.pdf 
4. Bulgarian Unit of International Network of UNESCO Chair in Bioethics (in Eng.). Available at: http://www.ichle.com/87091/Bulgarian-UNESCO-Unit

5. Cross-Cultural Bioethics at an International University in Japan. Philosophy Study, ISSN 2159-5313May 2012, Vol. 2, No. 5, 362-369 [in Eng.]

6. Evaluation of Bioethics. [in Eng.]. Available at: http://wings.buffalo. edu/faculty/ research/bioethics/eval.html

7. International network of UNESCO Chair in Bioethics. Austria [in Eng.]. Available at: http://www.unesco-chair-bioethics.org/UI/C02.aspx?uid=C8CC 1706BD1214DE

8. Koc Univercity, Summer course on Research Methoology and Ethics in Health Sciences. (in Eng.). Available at: http://rmhs.ku.edu.tr/

9. Mammadov V. G., Mustafayeva A.I. "The role and importance of bioethical issues in medical law lecturing”. Program and Materials of the VI AllUkranian (V International) Scientific-Practical Conference on Medical Law, Lviv, Ukraine, 26-28 April 2012, pp. 219-224 [in Eng.].

10. Mammadov V.G. "Bioethics education in the system of medical education in CIS countries." Abstracts Book of the 19th World Meeting of the International Association of Forensic Sciences (IAFS), 5th Meeting of the Mediterranean Academy of Forensic Sciences (MAFS), 9th Triennial Meeting of the World Police Medical Officers (WPMO), Funchal, Madeira, Portugal, 12-17 September 2011, p.833 [in Eng.].

11. Mammadov V. G. "Bioethics developments in Azerbaijan". Program and Book of Abstracts - Bioethics 2012. UNESCO Chair in Bioethics 8th İnternational Conference on Bioethics Education: Content, Methods, Trends. Tiberias, Sea of Galilee, İsrael, September 2-5, 2012, p.113. [in Eng.].

12. Mammadov V. G. "Recent Developments in Bioethics and Medical Law in Azerbaijan Assessed by UNESCO as Pioneer in the Region." World Association for Medical Law Newsletter. April-June 2012, v. 4, issue 2 (13), pp.4-6. [in Eng.]. 
13. Mammadov V. G. "Recent developments of medical law and bioethics in Azerbaijan”. Medichne Pravo. ISSN 2072-084X, no. 1 (11) 2013.- Lvov, Ukraine - pp. 43-53 [in Eng.].

14. Mammadov V.G. "Bioethics-Azerbaijan". Chapter in book: R.G.Beran (ed.), Legal and Forensic Medicine. Springer-Verlag Berlin Heidelberg, 2013, P.1171-1115 [in Eng.].

15. Mammadov V.G. "The challenge and tasks of UNESCO Bioethics Chair Focal Point in Azerbaijan." Program and Book of Abstracts of the $18^{\text {th }}$ World Congress on Medical Law, Zagreb, Croatia, 8-12 August 2010, p.141 [in Eng.].

16. Mammadov V.G., Munir K.M., Jafarova L.A. Medical Science, Research And Higher Education in Azerbaijan from Bioethical Developments Perspective Medichne Pravo [Medical Law] 2(18) 2016 [in Eng.].

17. Mammadov V.G., Mustafayeva A.I, Ahmadov I. "Bioethical principles key methodological tools in modern teaching of medical law". Program and Materials of the VI All-Ukranian (V International) Sci.-Pract. Conf. on Medical Law, Lviv, Ukraine, 26-28 April 2012, p.225-231 [in Eng.].

18. Mammadov V.G., Mustafayeva A.I, Hasanova V. Rol i vajnost bioeticheskix voprosov $\mathrm{v}$ prepodavanii medicinskogo prava [Role and importance of bioethial issues in teaching of medical law].Intern. law and problems of integration. Sci.- Analyt. and Pract. journal, no.2(26), 2011. Baku State Univ., pp. 26-36.

19. Mammadov V.G, Mustafayeva A.I. Teaching of legal aspects of bioethical norms in the system of higher education of Azerbaijan. Materials of Int. Conf. Teaching of Bioethics: content, methods, trends. UNESCO Committee in Bioethics, Kanaan Spa, Zefat, Israel, 2-5 May, 2010, pp. 60-61 [in Eng.].

20. Mammadov V.G, Ahmadov I., Mustafayeva A.I, and others "Bioethics education in Azerbaijan: content, methods, trends and perspectives". Program and Book of Abstracts - Bioethics 2012. UNESCO Chair in Bioethics 8th İnternational 
Conference on Bioethics Education: Content, Methods, Trends. Tiberias, Sea of Galilee, İsrael, September 2-5, 2012, p.3. [in Eng.].

21. Mustafayeva A.I., Programma YUNESKO po bioetike [UNESCO Programme on Bioethics] "Bioetika: Senedler...Terminler..." [Bioethics...Documents.Terms] Baku, 2009. pp. 77-78.

22. Mammadov V.G, Ahmadov I. "YUNESKO-nun Bioetika üzrə baza tədris proqramının mahiyyəti və vacibliyi haqqında" [About essence and importance of UNESCO Core Curriculum] "Bioetichs, Medical Law and New Technologies". ANAS Institute on Human Rights. Baku. 2011. pp. 65-67 [in Aze.].

23. Promoting bioethics - The contribution of UNESCO. 16th Session of the International Bioethics Committee Mexico City, 23-25 November 2009 [in Eng.]. Available at: http://www.unesco.org/new/fileadmin/MULTIMEDIA/ HQ/SHS/ pdf/tenhave_unesco_programme.pdf

24. Realoizaciya programmi YUNESKO po bioetike $\mathrm{v}$ Azerbaijane [Realization of UNESCO bioethics Programme in Azerbaijan] IHR of ANAS. Available at: http://www.ihr-az.org/index.php?lang=3\&ind=conf\&id=34\& page $=0 \& p r \_i d=0 \& c a t \_i d=0$

25. Sostoyanie prepodavaniya bioetiki $\mathrm{v}$ sisteme medicinskogo obrazovaniya v gosudarstvax-uchastnikax SNG. Analiticheskiy obzor. Ed. by Kubar O.I. [The state of the teaching of bioethics in the system of medical education in the CIS member states]. Analytical review. Saint-Petersburg, 2010, p. 119.

26. UNESCO. Latin America and the Caribbean [in Eng.]. Available at: http://www.unesco.org/en/university-twinning-and-networking/access-by-region /latin-america-and-the-caribbean/mexico/unesco-chair-in-bioethics-950/

27. Universal Declaration on Bioethics and Human Rights [in Russ.] http://www.un.org/ru/documents/decl_conv/declarations/pdf/bioethics_and_hr.pdf 